\title{
Implementation Model of Zonation System Policy in Admission of New Junior High Schools Students in Bandung Regency
}

\author{
Koko Enang* \\ Nurtanio University \\ Bandung, Indonesia \\ kokoenang57@gmail.com
}

\author{
Bambang Heru Purwanto, Rully Indrawan \\ Pasundan University \\ Bandung, Indonesia
}

\begin{abstract}
Inequality in education quality still transpires in several regions in Indonesia, one of them is in Bandung Regency where the obvious rift in the quality of education remains. One intention to reform and equalize the quality of education is the implementation of the zoning system to the proceeding of accepting new students. Provisions are enclosed in Local regulation No. 33 of 2018 and the policy on Admission of New Students for the Junior High School Zoning System. This study intends to determine the implementation of the Admission of New Junior High School Students Zoning System Implementation Model in Bandung Regency, to know what the factors that not sufficient yet for the Admission of New Junior High School Students zoning system are, and to find the right model which can reform the Admission of New Junior High School zoning system. The research method that the author used in this study is a mixed method, which is a combination of qualitative methods with quantitative methods with a Concurrent Embedded Strategy Approach. The results showed that the Mentality Approach was quite optimal in the implementation of policies which are seen from the attitude of the government, the behavior of the government, and the responsibility of the government in implementing the Admission of New Junior High School Admission Policy with the Zoning System. Admission of New Students in Junior High School of the zoning system conducted by the Bandung District Education Office showed that the mentality of the bureaucracy and the community are not optimal. It means that the community always looks for rifts in carrying out the Admission of New Junior High School zoning system in disparate ways. The system built by the bureaucracy is good enough, but there are still shortcomings and not synergistic all parties yet in implementing the Admission of New Junior High School zoning system. Networking built by the bureaucracy still does not reverse the wishes of the community, because the interests of the bureaucracy and the interests of the community have not shown maximum results.
\end{abstract}

Keywords—model, policy implementation, zoning system

\section{INTRODUCTION}

Law of the Republic of Indonesia Number 20 of 2003 [1], Noticing the National Education System states: Education is a conscious and planned intention to spawn an atmosphere of learning and learning proceeding so that students actively flourish their potential to have religious, spiritual fortitude, self-control, personality, intelligence, noble morals, as well as the expertise needed by himself, society, nation and state. Education plays a very important role in educating the life of the nation and the stride of a nation therefore every settler is given the same fortuity to take education. This makes Education a basic right of settlers. Then all Indonesian settlers are entitled to education and teaching. The government is obliged to fulfill the rights of every settler in obtaining education services.

One of the real intentions of the government in the framework of the equalization of education is the government issued a new regulation in accepting students through the Minister of Education and Culture Regulation No. 17 of 2017 concerning New Student Admission, in the Minister of Education and Culture Regulations, it is regulated that the zoning system, schools must implement it in accepting new students [2]. New students who live in the closest zone radius of the school are at least 90 percent of the total number of students accepted. The domicile of new students is based on the address on the family card issued no later than six months before the implementation of the Admission of New Students. The closest zone radius is determined by the local government in accordance with the conditions in the area, which is another 10 percent, that is, five percent for achievement paths, and five percent for students who experience domicile transfer.

The problems of Admission of New Junior High School Students in the zoning system in Bandung Regency are (1). The mindset of the community formed and has become a character that there are several schools that are considered favorable. (2). Lack of socialization of policy understanding towards education stakeholders both internally in the Bandung District Education Office, the Technical Implementation Unit of the Office, Schools and externally, namely the community. (3). The government's behavior in implementing the Admission of New Junior High School Policy zoning system has not created a sense of justice for the community. (4). The behavior of people who are always looking for loopholes to include their children in disparate ways. (5). For parents who are capable in 
the economic field, with the zoning system cannot choose the desired school because it is limited by zoning.

\section{LITERATURE REVIEW}

\section{A. Public policy}

The thought of public policy in the language of administration according to Thoha [3] has long been recognized. After being explored, the thought of public policy stems from the thought of decision-making process. A topic of discussion in administration follows the expansive development in administrative science following the development of the scope of administrative science as expansive as the activities of the country itself. This development makes the thought of decision-making process not simple because it is related to expansive and diverse communal issues and the complexity of the problems that must be faced by government organizations and the country's political system. This is where the thought of decision-making process develops into public policy. Furthermore, William N. Dunn [4] in Pasalong said that: "Public policy is a series of interconnected choices made by government institutions or officials in fields related to governmental undertakings, such as defense, security, energy, health, welfare education society, crime, urban areas and others."

David Easton as quoted by Leo Agustino [5] provides a definition of public policy as: "The authoritative allocation of values for the whole society". This definition confirms that only the owner of authority in the political system (government) can legitimately conduct something in society and the government's choice to do something or not do something is manifested in the form of allocating values. This is because the government is included in the "authorities in a political system" which means the rulers in the political system are involved in the affairs of the daily political system and have responsibilities in a particular problem where at some point they are asked to take settlements later accepted and binding on most members of the community for a certain time.

The policies above can be concluded that public policy is made by the government in the form of government actions. Public policy must be oriented to the public interest. It is an alternative choice of action to be carried out by the government in the public interest, ideally it is implemented in the real form, not merely stated, it is implemented or not because it is based on the public interest itself.

\section{B. Public Policy Implementation}

As a logical consequence that the stages of policy implementation need to synergize the role and existence of the three dimensions of stakeholder policy that can be realized and actualized through a Mentality, System, and Networking approach or Policy Implementation Model through MSN Approach. It can be seen in Figure 1 as follows:

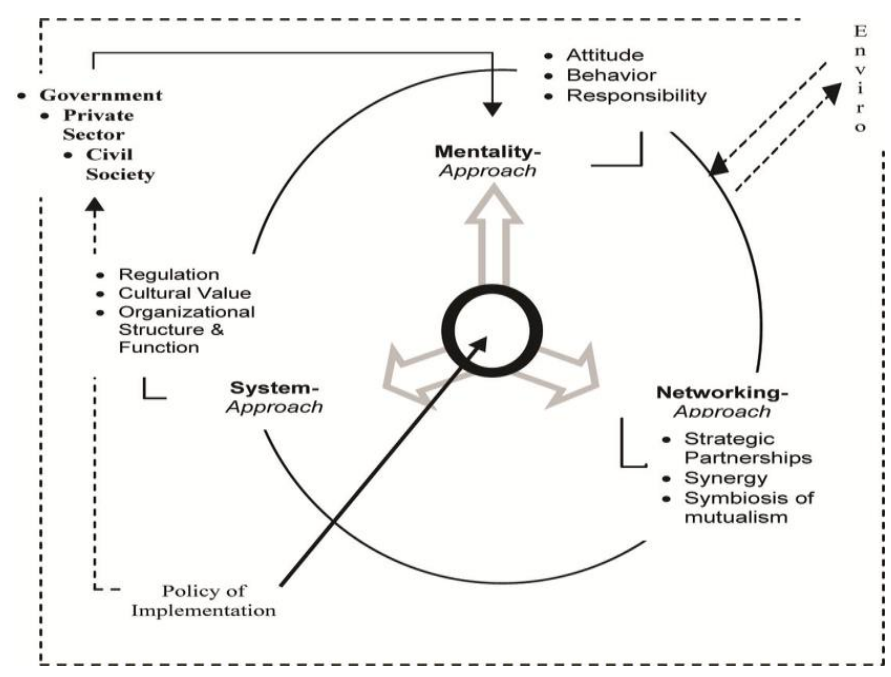

Fig. 1. MSN -Approach Model (YK Model [6]).

Yulianto Kadji's model is a public policy that will be actualized and directed in its implementation, if it uses or pays attention to at least what is called the MSN Model or a Mental, System, and Network approach of cooperation between government, private and community.

\section{RESEARCH METHODS}

The research method that the author uses in this study is a mixed method, which is a combination of qualitative methods with quantitative methods with a Concurrent Embedded Strategy Approach [7]. Authors collect quantitative and qualitative data together (at one time), then each of the data is analyzed and concluded.

Data collection is conducted by interview, observation, and documentation. The data analysis technique used in this study is a descriptive analysis. The data that has been obtained is then analyzed to answer the problem formulation and research questions that have been made.

Data that has been analyzed, then made criteria by using a table of variable tendencies to see the level of approval/ admission of new students with the zoning system. Furthermore, the results of the study are concluded.

\section{RESULTS}

The policy model in increasing the effectiveness of the implementation of the new student admission policy in the zoning system of junior high school. Based on the results of the study, the authors analyzed the model of policy implementation Regulations No. 33 of 2018 Regents and policies on the Guidelines and Committee for the Implementation of New Student Admissions for Basic Education in 2018-2019 Academic Year in Bandung Regency [8]. Policy implementation Ministerial Regulation No. 17 of 2017 concerning Admission of New Students in Basic Education, High Schools, Vocational Schools and Regulations of the 
Regent No. 33 of 2018 About the Committee for Admission of New Students in Basic Education in Bandung Regency. Implementation carried out by the Office of Education is implementing three zones, namely zone 1 which is carried out by the Technical Implementation Unit of Office 1 Soreang, which is 9 (nine) Districts. Baleendah region 2 Technical Service Implementation Unit, namely 11 Districts. There are 11 District Technical Implementation Units in the Solokanjeruk area.

The three zoning and closest zone models conducted by the Bandung District Education Office reap the pros and cons of the community because many parents complain that their children cannot be accepted at the closest dwelling school but are not accepted because zoning calculations are very decisive, even though there is a region for example Not all Katapang Public Junior High Schools are accepted at the school. With the inclusion of the Bandung District Education Office in implementing the Admission of New Middle School Students based on the zoning system based on Ministerial Regulation No. 51 of 2018 concerning Admission of New Students for Elementary Schools [9], High Schools and Vocational Schools and Regents of Regulations No. 30 of 2019 About Procedures for Admission of Students New Basic Education Levels 20192020 .

This is in accordance with the theoretical model developed by Yulianto Kadji [6] which states that as a logical consequence that the stages of policy implementation need to synergize the role and existence of the three dimensions of stakeholder policy that can be realized and actualized through mentality, systems and networking approaches or models Policy Implementation Through MSN -Approach. Yulianto's perspective is not optimal enough to explain the implementation of policies in the implementation of New
Student Admissions with the zoning system. Evidenced by the role of the central government holds the key in the implementation of this policy. When the central government policy, namely the Education Office is in line with local government policy, the resulting implementation will be better. On the other hand, if the central policy is not in harmony with the region, the policy implementation is less successful.

According to this perspective, the results show that Mentality - Approach seen from the government attitude, government behavior and government responsibilities is quite optimal.

The author combines the Yulianto Kadji model with the community perception model. The author tries to flourish a perception model that develops in the community arises from a dissatisfaction or The Admission of policies issued by the government, so that people have an opinion about it. This is in line with Kottler's [10] perception theory as follows: Perception is the proceeding in which an individual chooses, organizes, and interprets information inputs to spawn a meaningful picture of the world. Perception does not only depend on physical stimulation, but also on the relationship of stimulation with the surrounding fields and on the conditions within the individual. The key word is individual. Individuals can have different perceptions of the same object because of three proceedings of perception: selective attention, selective distortion, and selective retention.

Both opinions are that perception is a statement or view from the community on a problem that develops in the community that raises the pros and cons or accepts and the community evaluates and provides views or perceptions about the problem. The relationship of research results by modifying Yulianto Kadji's theory and the perception theory that authors developed can be seen from Figure 1 as follows:

\section{MODEL OF ADMISSION OF NEW STUDENTS IN JUNIOR HIGH SCHOOL IN BANDUNG DISTRICT}

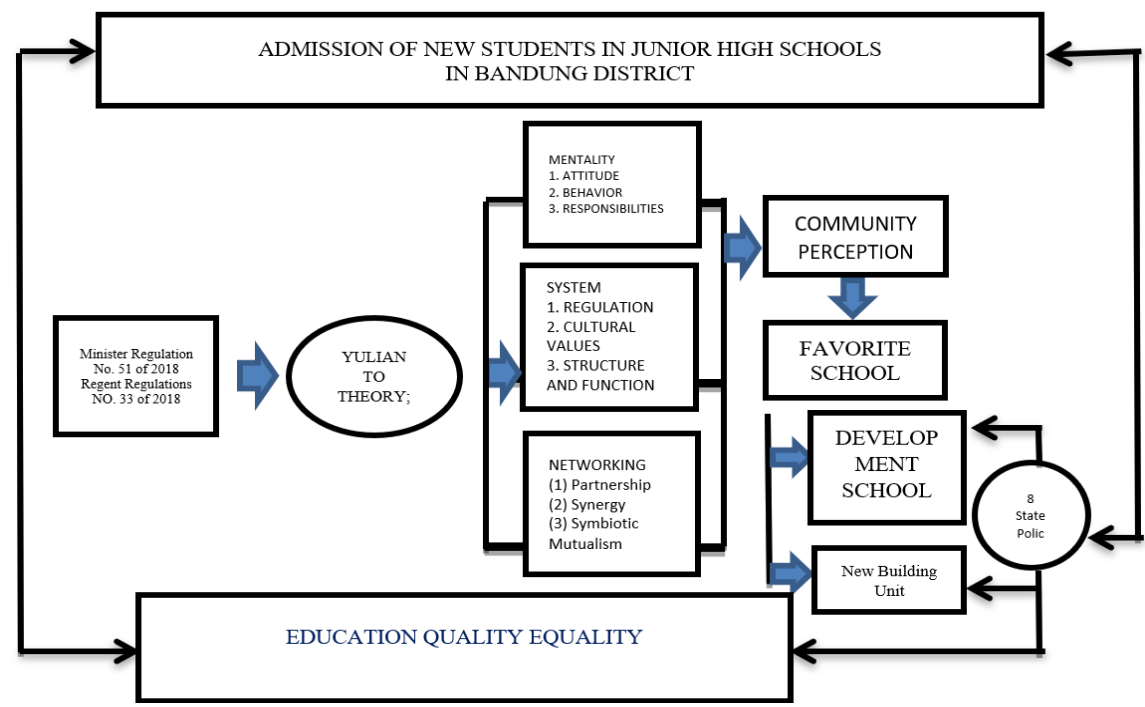

Fig. 2. Relationship between Research Results and the modification of Yulianto's Theory and Perception Theory. 
The implementation of new junior high school student admission zoning system is currently the zoning of the nearest school not the zoning area, what is desired by the authors is the three points namely favorable zoning, development zoning, and zoning of the New Building Unit. This favorite zoning and development must be zoned and controlled by a favorite school with 50\% Admission of the closest school zone with $50 \%$ achieving. The reason why favorite schools and development are put together, and the percentage is balanced because to get the trust of the community, so that development schools will pursue becoming favorite schools. Furthermore, the New Building Unit is a pure zoning that requires an increment in eight education requirements to pursue both zoning, so that the equality of education will be achieved or born without losing public perception of favorite schools.

\section{CONCLUSIONS AND SUGGESTIONS}

\section{A. Conclusions}

Based on the results of research conducted by the author in Bandung Regency, that the Admission of Junior High School Students zoning system conducted by the Bandung District Education Office by using the MSN approach theory, mentality approach, system approach, and networking approach. That's the mentality of the bureaucracy and the mentality of the community are still not optimal, which indicate that the community is always looking for a chance to make deviations in the implementation of the New Student Admission of Junior High Schools zoning system in disparate ways. The system built by the bureaucracy is good enough, but there are still shortages yet synergistically all parties in implementing the Admission of New Student of Junior High School zoning system. The network built by the bureaucracy still does not reverse the wishes of the community, because there are still bureaucratic interests and the interests of the community that are not yet satisfied.

The model of policy implementation carried out by the Bandung District Education Office, namely the three zoning models implemented by the Regional Technical Implementation Units of Regions 1, 2 and 3 using the zoning closest to the school, has not been satisfactory, nor is the ninezoning model using this zone of zones who are not satisfied.

\section{B. Suggestions}

Based on the conclusions above can be recommended as follows:

- Accommodate community aspirations and conditions in certain regions due to the uneven number of schools in disparate regions. This can be done by making adjustments to the extent that it does not deviate from the main purpose of zoning.

- Favorite or superior schools should not be eliminated because building quality requires a proceeding from starting to reform human resources, infrastructure, quality of graduates, and so on. This should be used as a reference by the government to flourish schools in areas where the quality is still low.

- Socializing the zoning system with a massive and long socialization time related to the Admission system of new students, so that it will not cause misunderstanding in a society that has a diverse paradigm.

- Optimizing coordination between the central and regional governments, the government and officers in each school and the community.

- The government needs to immediately realize eight educational requirements from the city to the countryside, as well as a more concrete distribution of educational facilities and quality, so that the distribution of education can be felt by the community. Improving the quality of human resources or teachers, improving infrastructure and facilities used later by students.

- The mentality of the community in choosing a favorite school is still very strong and needs to change their views or mentality.

\section{REFERENCES}

[1] Law No 20 of 2003 concerning the National Education System

[2] Government Regulation No 17 of 2017 Noticing Admission of New Students

[3] M. Thoha, Perilaku Organisasi, Konsep Dasar, dan Aplikasinya. (Jakarta: PT Raja Grafindo Persada). 2014

[4] W.N. Dunn, Public Policy Analysis: An Introduction. (New Jersey University of Pittsburgh). 2000.

[5] Agustino, Leo. (2016) Dasar-Dasar Kebijakan Publik Edisi Revisi, Penerbit Alfabeta Bandung

[6] Y. Kadji, Formulasi dan Implementasi Kebijakan Publik Penerbit Gramedia. 2018

[7] J.W. Creswell, Research Design. Pendekatan Kualitatif, Kuantitatif dan Mixed, (Yogyakarta: Pustaka Pelajar). 2013.

[8] Regent Regulation No 33 of 2018 Noticing Admission of New Students to the Zoning System.

[9] Government Regulation No 51 of 2018 Noticing Admission of New Students

[10] P. Kotler, Marketing Management Millenium Edition, Custom Edition For University Of Phenix. 2002 